\title{
Efficiency of Dissimilar Friction Welded (Super Duplex Stainless Steel SAF 2507- Mild Steel) Joints
}

\author{
Ramadhan H Gardi * \\ *Mechanical Department \\ College of Engineering \\ Salahaddin University-Erbil/Iraq \\ E-mail:ramadhanhg@yahoo.com
}

\author{
Salm Aziz Kako** \\ ** Mechanical Department \\ Foundation of Technical Education \\ Erbil Technical Institute \\ E-mail:salm_zz@yahoo.com
}

\begin{abstract}
The aim of this research paper is to investigate the efficiency of dissimilar friction welded super duplex stainless steel SAF 2507 and mild steel joints. The joints were obtained using rotary friction welding process. Friction pressure and forging pressure are varied in three different cases but rotational speed and friction time are kept constant .The joints were subjected to tensile strength and metallographic study. The tensile strength of welded joints compared to that of SDSS SAF 2507 and mild steel in as received condition. The joint efficiency were calculated .The tensile strength and joints efficiency decreased with increasing friction pressure and forging pressure .The results attributed to change in mechanical, physical properties , and micro structural changes of welded joints like change in ferrite to austenite percent, precipitation of carbides and nitrides ,sigma phase,....etc.
\end{abstract}

Key words: Friction welding, super duplex stainless steel, tensile strength

$$
\begin{aligned}
& \text { "كفاعة وصلاة اللحام الاحتكاكى غير المتثابه بين الصلب المقاوم للصدأ المزدوج }
\end{aligned}
$$

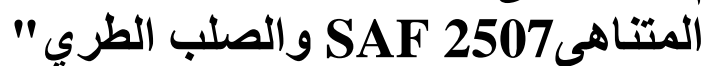

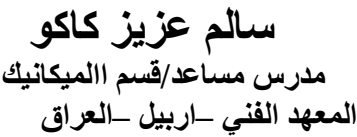

\section{الخلاصة}

الغرض فى هذا البحث هو دراسة كفاعة وصلات اللحام الاحتكاكى غير المتشابه بين الصلب المقاوم للصدآ

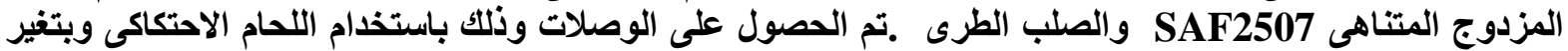

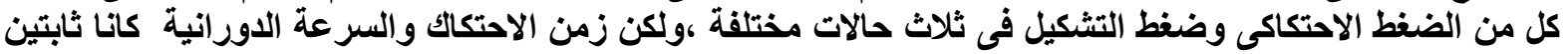

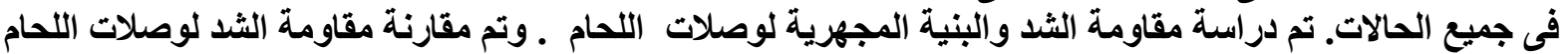

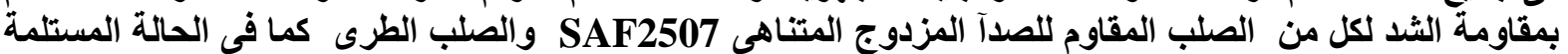

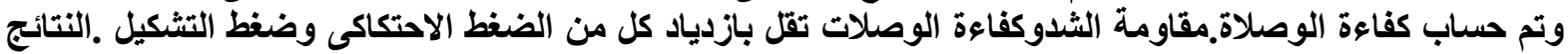

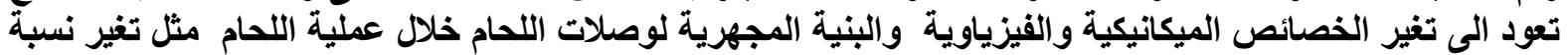

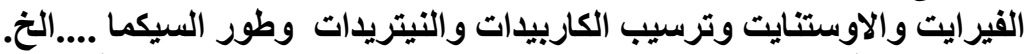

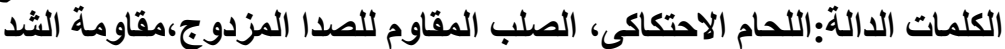




\section{Introduction:}

Duplex stainless steels DSS are iron (Fe)-Chromium (Cr)-Nickel (Ni) alloy with approximately equal volume fraction of ferrite and austenite .Ferritic stainless steels have high yield strength and good stress corrosion resistance but show brittleness and poor ductility, while austenitic stainless steels have high toughness, but they are sensitive in local corrosion in chloride environment and have low yield strength [1]. The dual phase microstructure of duplex stainless steels combines attractive properties of austenitic and ferritic stainless steels. SDSS SAF 2507 is used in oil and gas industry ,tubing for heat exchanger ,refineries, pipe for sea water transport, propeller shafts and other products subjected to high mechanical loads in sea water and other chloride containing environment[2].

Duplex stainless steels and mild steel are widely used materials due to their excellent mechanical and physical properties .In engineering applications and under some particular circumstance the welding of these two dissimilar materials is mandatory and it is important to produce high quality joints between them .Among different types of welding technique to join materials, friction welding is more acceptable compared to fusion welding processes because of advantages such as high material saving ,low production time limited heat effected zone .Friction welding can be used for welding similar and dissimilar counterparts even with a great difference in mechanical and metallurgical properties like melting point(tungsten and copper),low melting point materials (copper and aluminum) and material strength (stainless steel and pure aluminum)[3].Friction welding classified as a solid state joining process in which bonding is produced at a temperature lower than the melting point of base materials .The most important parameters in friction welding are friction pressure, forging pressure, friction time, and rotational speed.

Sahin and Akata [4] directed an experimental study on dissimilar friction welded carbon steel and austenitic stainless steel. Satyanarayanan et al [5]studied the effect of roughness of faying surface of austenitic stainless steel on friction welded dissimilar joints with ferritic stainless steel, they found that notch tensile strength will increase with increasing roughness up to critical value and thereafter a descending trend is noted .A.Kurt [6] studied mechanical properties of dissimilar friction welded mild steel and bronze joints and they reported that the tensile strength of dissimilar joint can reach $70 \%$ of base metal strength. A. Hascalik et al [7] studied fatigue behavior and tensile strength of friction welded dissimilar AISI 304 austenitic -AISI 4340 ferritic stainless steel joints and concluded that the tensile strength and fatigue endurance will decrease with increasing rotational speed during friction welding process. Eder Padun Alves et al [8] reported that tensile strength of dissimilar friction welded AISI 304 stainless steel and AA 1050 aluminum is higher than that of fusion welding processes.

Although large number of friction welded dissimilar material have been reported up to date the information about dissimilar friction welded super duplex stainless and mild steel is very scare .The aim of this study is to examine efficiency of dissimilar friction welded( super duplex stainless steel SAF 2507 - mild steel ) joints.

\section{Experimental procedure}

\section{Materials:}

The work piece materials used in this study are super duplex stainless steel (SDSS) SAF 2507 and mild steel (MS). The dimensions of materials are $20 \mathrm{~mm}$ diameter round bars and $60 \mathrm{~mm}$ length. The chemical composition of work piece materials are given in table 
(1).Chemical composition detected using (spectrometer metal analyzer model spectromaxx, Spectro Company, Germany 2010). Microstructure of SDSS and mild steel in as received condition are shown in figures (1) and (2) respectively.

Table (1) Chemical composition of super duplex stainless SAF2507 and carbon steel

\begin{tabular}{|l|l|l|l|l|l|l|l|l|l|l|}
\hline Material & Cr\% & Ni\% & C\% & Mo\% & Mn\% & P\% & N\% & Si\% & S\% & Fe \\
\hline SAF2507 & 25 & 7.8 & 0.03 & 4 & 1.1 & 0.03 & 0.25 & 0.8 & 0.01 & Bal \\
\hline mild steel & 0.022 & 0.06 & 0.1 & 0.001 & 0.69 & 0.006 & 0.014 & 0.24 & 0.24 & Bal \\
\hline
\end{tabular}

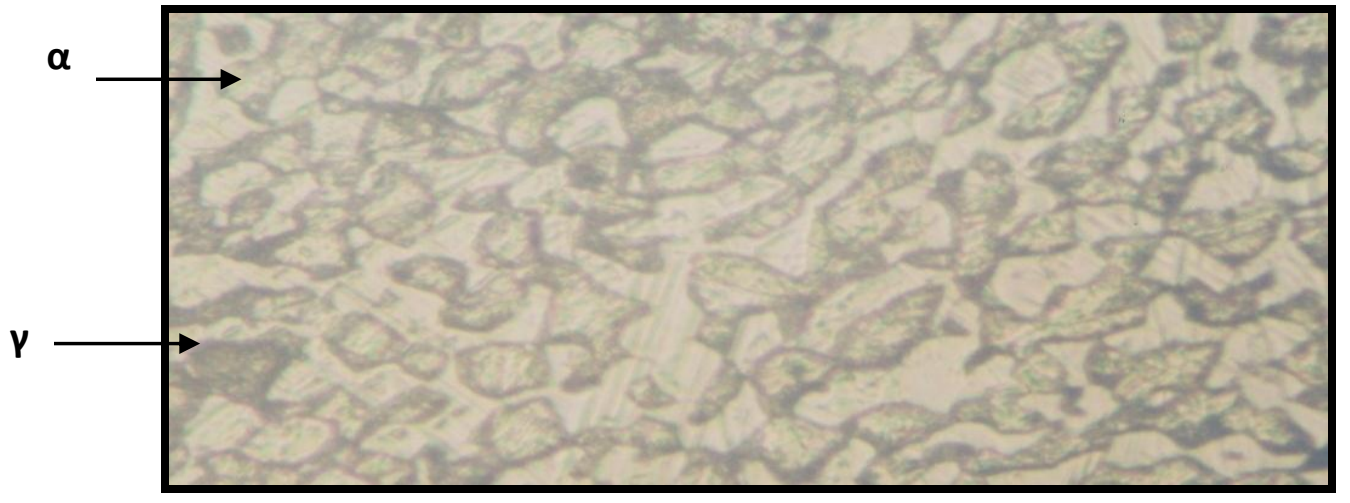

Fig.(1) Microstructure of as received super duplex stainless steel SAF 2507(x600) $\alpha=$ Ferrite,$\gamma=$ Austenite

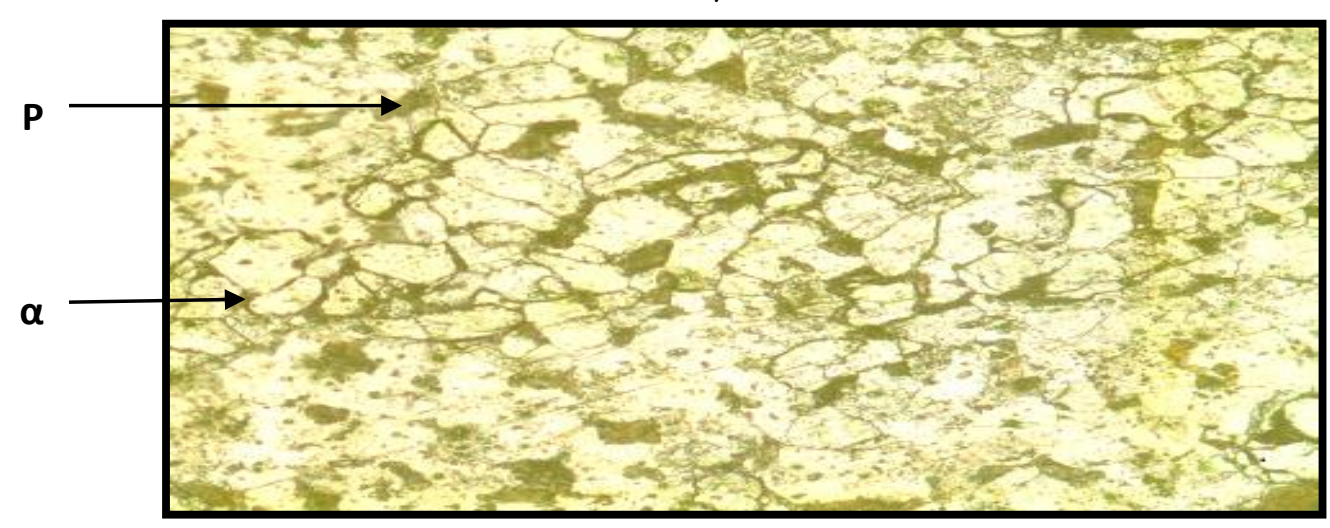

Fig. (2) Microstructure of as received MS (X600)

$$
\mathrm{P}=\text { Pearlite }
$$

\section{Friction Welding:}

Friction welding was conducted using a continuous drive friction welding process at rotational speed of $1800 \mathrm{rpm}$. Super duplex stainless steel sample is fixed in a rotating member while mild steel sample is fixed in a stationary member. The friction welding parameters used in this study are shown in table (2).The axial length shortening of samples was calculated by measuring the length of samples of different materials before and after welding

Table (2) Friction welding parameters for different cases

\begin{tabular}{|c|c|c|c|c|}
\hline Case & $\begin{array}{c}\text { Friction } \\
\text { pressure } \\
{[\mathbf{P 1}] \mathbf{M P a}}\end{array}$ & $\begin{array}{c}\text { Forging } \\
\text { pressure } \\
\text { [p2]MPa }\end{array}$ & $\begin{array}{c}\text { Friction } \\
\text { time } \\
\text { (second) }\end{array}$ & $\begin{array}{c}\text { Friction } \\
\text { speed (rpm) }\end{array}$ \\
\hline I & 33 & 80 & 20 & 1800 \\
\hline II & 53 & 90 & 20 & 1800 \\
\hline III & 80 & 134 & 20 & 1800 \\
\hline
\end{tabular}




\section{Metallographic analysis:}

The welded samples subjected to standard metallographic preparation to examine the microstructure. The specimens were first mechanically polished with the emery paper and then etched chemically according to ASTM standard solutions [9] as follow:

a) For super duplex stainless steel SAF 2507, the solution consist of saturated solution of $\mathrm{FeCl} 3$ in $\mathrm{HCl}$ to which a little $\mathrm{HNO} 3$ is added and etching time equals to five minutes.

b) For mild steel the solution is Nital, consist of $98 \%$ water and $2 \%$ HNO3 and etching time equals to fifteen seconds.

\section{Tensile Strength:}

After welding tensile test was performed using notch tensile test, the notch was located at the interface. Configuration of tensile specimen was shown in Fig. [3]. Tensile properties evaluated using (Terco MT 3037 Universal Tensile Machine, Sweden). The base material and joints parts were machined with (32) $\mathrm{mm}$ gauge length and (6) mm diameters in parallel parts. The boundary interface was set at the center.

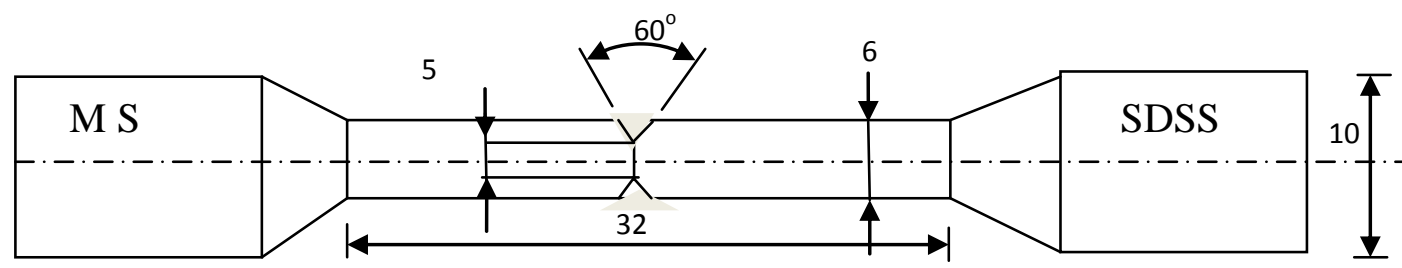

Fig. [3] Configuration of notch tensile strength

The joint efficiency is measured in terms of the tensile strength of the welded metal divided by the tensile strength of weaker metal of dissimilar metals [10] :

Efficiency of joint $=\frac{\text { Tensile strength of weld joint }}{\text { Tensile strength of softer metal }} X 100 \%$

\section{Results and Discussions}

The effect of friction welding parameters (friction pressure and forging pressure) on the axial shortening of welded specimens is presented in figure (4).

The axial shortening length significantly increased with increasing friction pressure and forging pressure, this is due to high degree of working results plastic deformation in the form of flash. A view of Joints of super duplex stainless steel SAF 2507 and mild steel are shown in Fig. (5).

During dissimilar friction welding between SDSS SAF 2507 and mild steel the flash forms mostly on the mild steel side this is due to lower yield strength and melting temperature ,in addition the thermal conductivity and thermal expansion of mild steel are quite higher compared to that of

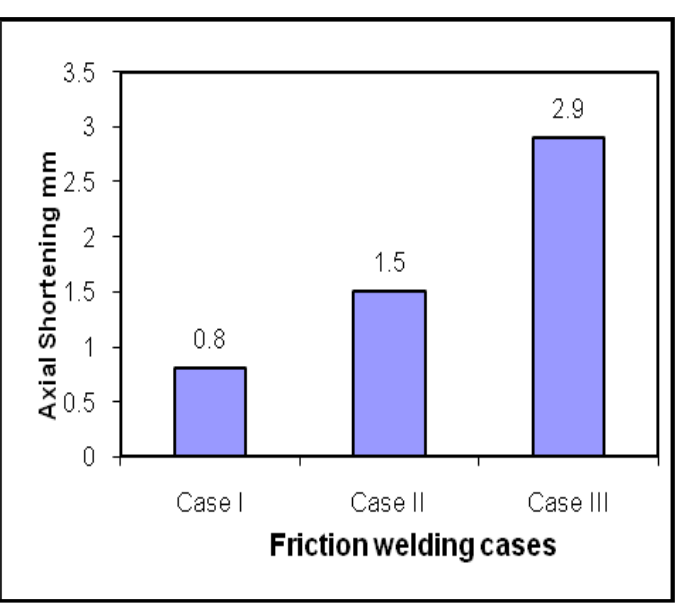

Fig.(4) Effect of friction welding parameters on axial shortening 
SDSS SAF 2507.Through the macrograph of the joints Fig.(5) it can be seen that the width of heat affected zone in mild steel side is greater than that of super duplex stainless steel side for all cases and increased with increasing friction pressure and forging pressure.

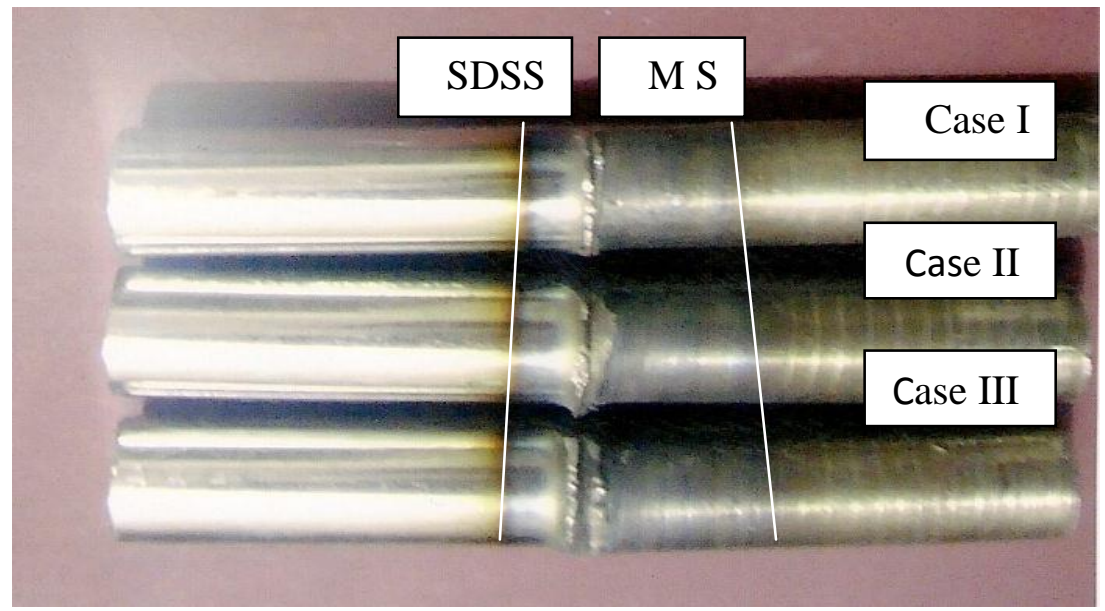

Fig. (5) A view of the dissimilar friction welded joints of SDSS SAF2507 and MS

The joint efficiency is calculated in terms of tensile strength, to investigate the tensile strength notch tensile strength was employed. The notch was located at the weld interface and plane tensile strength was not included as expected the fracture will be occurred at weaker metal (mild steel) outside of the weld interface and the obtained data would not represent the joint strength.

Fig.(6) and (7) shows the notch tensile strength properties of as received super duplex stainless steel and mild steel respectively.The ultimate tensile strength of SDSS SAF 2507 and MS are $1210 \mathrm{MPa}$ and $810 \mathrm{MPa}$ respectively.

The high tensile strength of SDSS SAF 2507 refers to dual phase equi axial ferritic austenitic microstructure while microstructure of mild steel consist of ferritic grains with nearly $12 \%$ pearlite. [figures(1) and (2)].

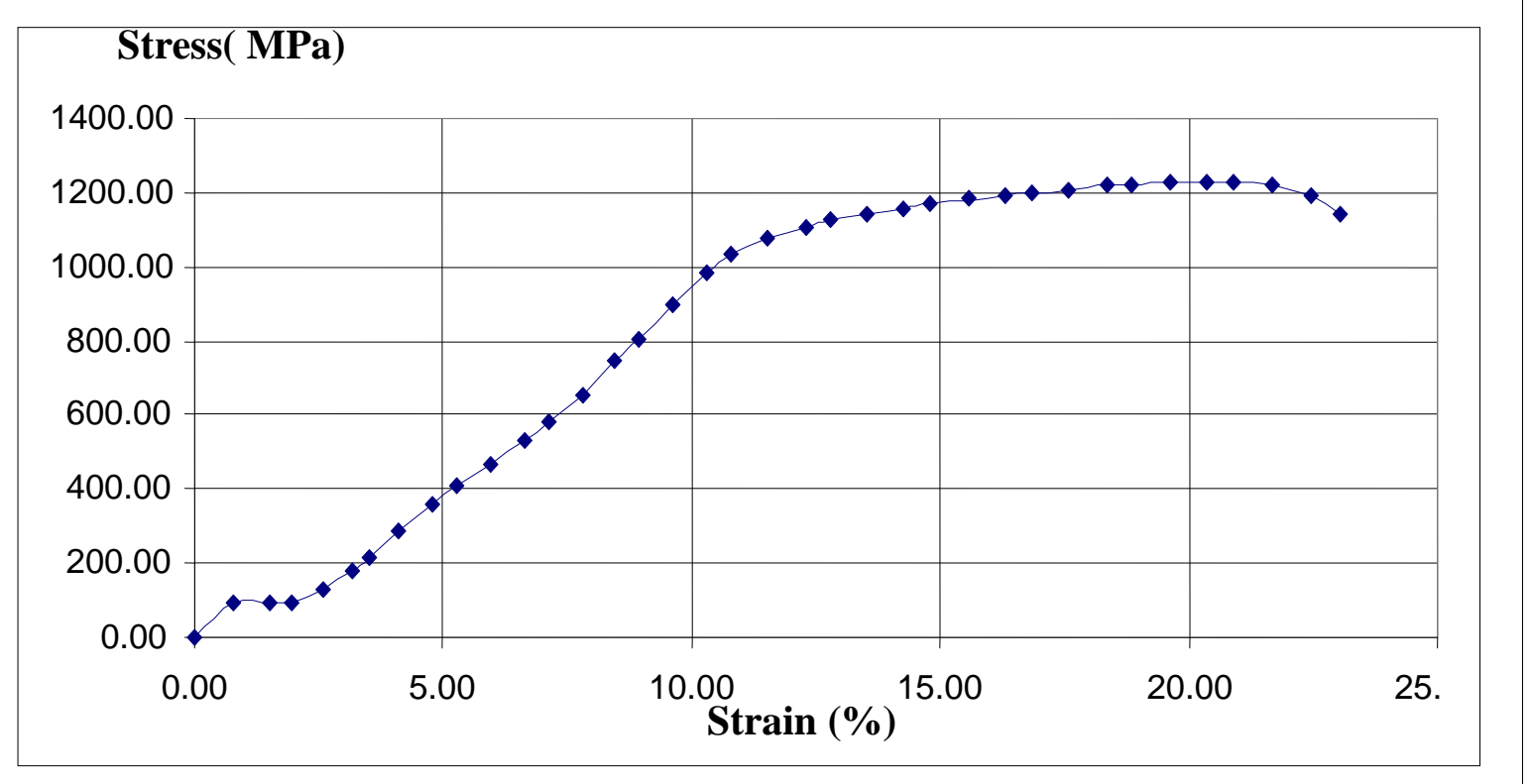

Fig. (6) Stress-Strain curve for as received SDSS SAF 2507 


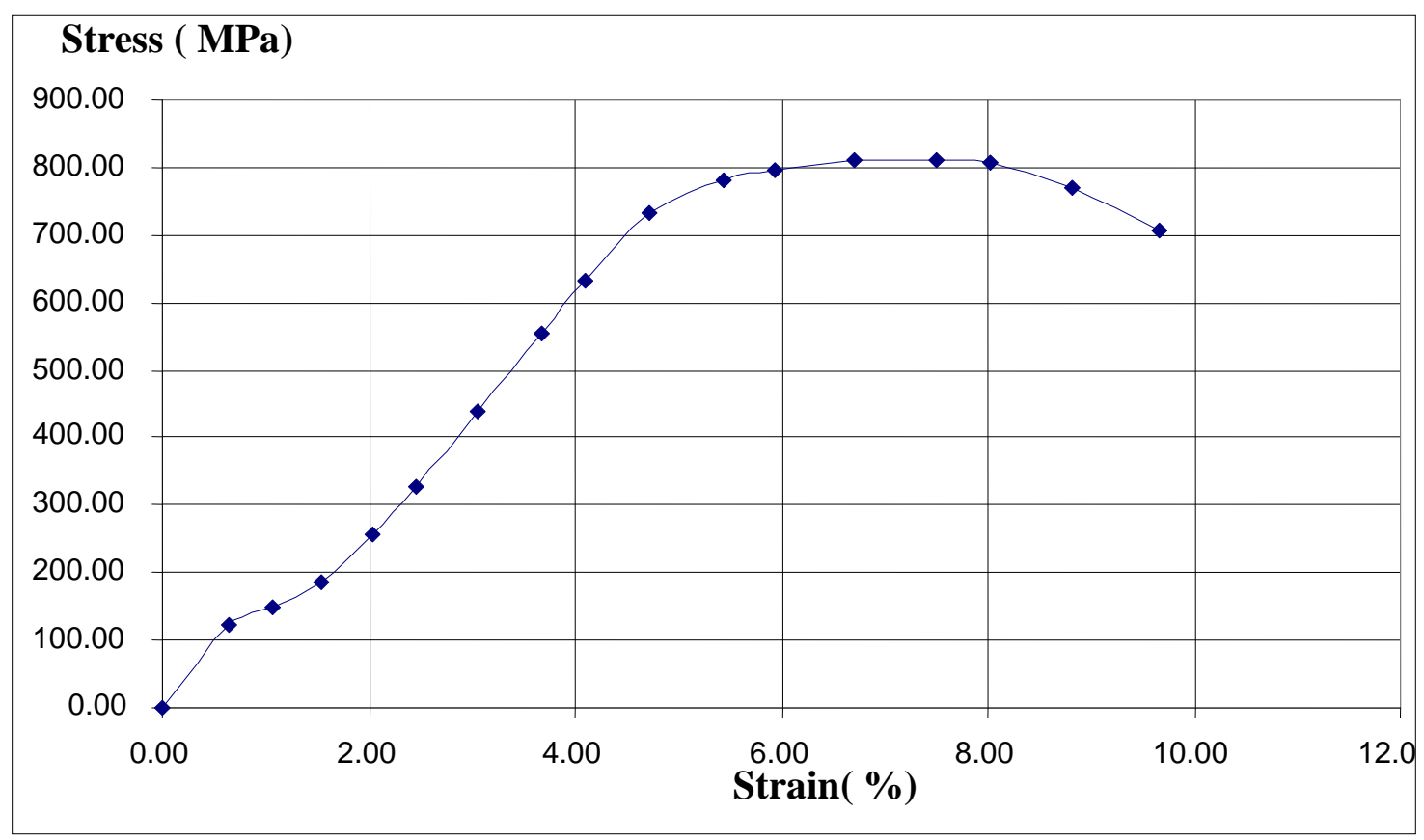

Fig. (7)Stress-strain curve for as received MS

The results of tensile strength and joint efficiency for three different cases welded with three different friction welding parameters are shown in table (3)

Table (3) Ultimate tensile strength and joint efficiency variation with friction welding parameters

\begin{tabular}{|c|c|c|c|c|}
\hline Cases & $\begin{array}{c}\text { Friction Pressure } \\
\text { MPa }\end{array}$ & $\begin{array}{c}\text { Forging } \\
\text { Pressure MPa }\end{array}$ & $\begin{array}{c}\text { UTS } \\
\text { (MPa) }\end{array}$ & Joint Efficiency \\
\hline Case I & 33 & 80 & 642 & $79.17 \%$ \\
\hline Case II & 53 & 90 & 568 & $74.96 \%$ \\
\hline Case III & 80 & 134 & 536 & $66.12 \%$ \\
\hline
\end{tabular}

The joint with highest ultimate tensile strength and joint efficiency refers to specimens welded in case I (lowest friction pressure and forging pressure) in which provide $642 \mathrm{Mpa}$ ultimate tensile strength, and this is lower than the tensile strength of weaker metal (mild steel) and this exhibit $79.17 \%$ joint efficiency .The results attributed to that the temperature of the specimen associated with this friction welding parameters and the time in which remains at this temperature is not sufficient to produce essential micro structural transformations. Figure (8) and (9) showed the microstructure of weld joint interface for DSS and M S side respectively for the specimens welded with lowest friction welding parameters (case I). 


\section{Gardi: Efficiency of Dissimilar Friction Welded Joints}

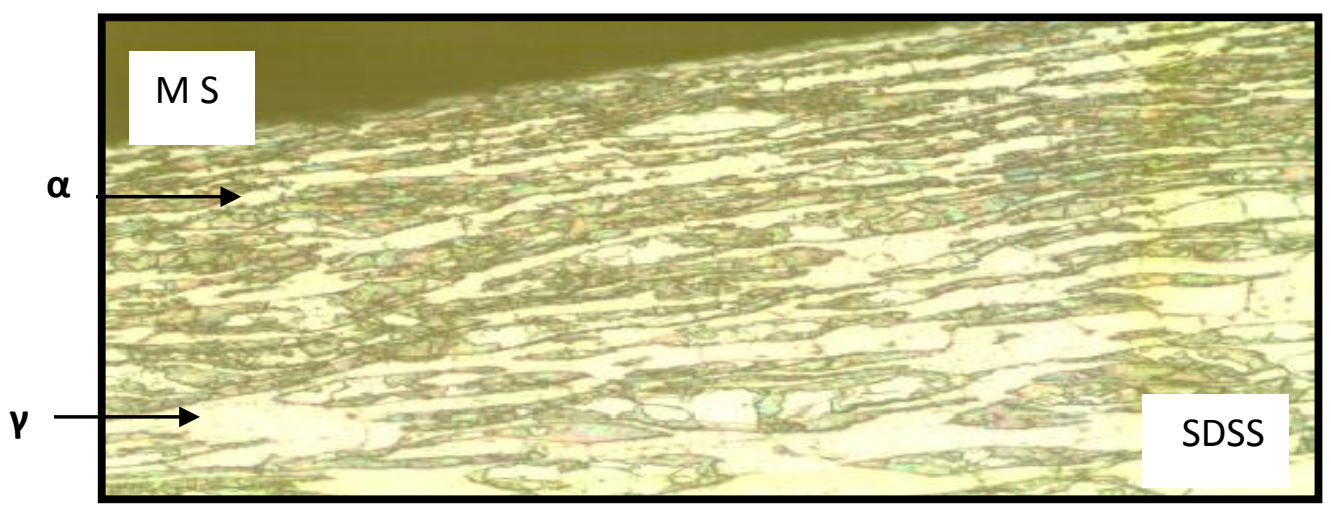

Fig. (8) Microstructure of dissimilar friction welded SDSS and MS joint interface (duplex side) case I (X600)

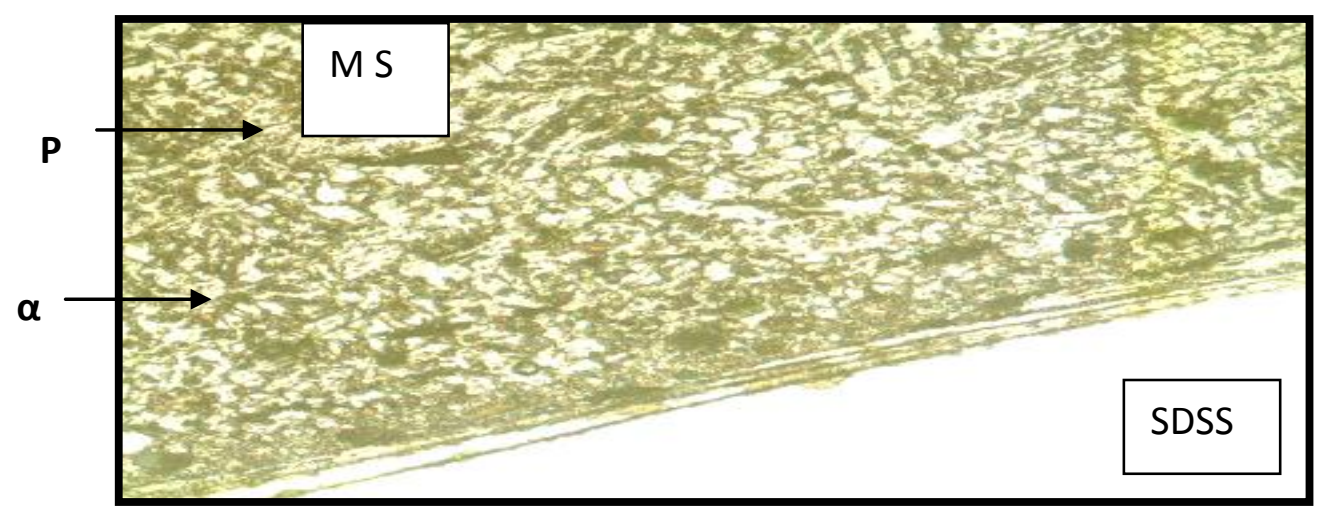

Fig. (9) Microstructure of dissimilar friction welded SDSS and MS joint interface (MS side) case I (X600)

Table (3) showed that when there is an increase in friction welding parameters the joint efficiency decreased gradually and reached to its minimum value $66.12 \%$ for the specimen welded with highest friction pressure and forging pressure (case III) this can be explained in terms that increasing bonding temperature due to increase friction pressure and forging pressure promotes the growth of brittle intermetalic $(\sigma)$ phases which adversely effect the bond strength. The low value of tensile strength and joint efficiency attributed to presence of sigma phase and chromium carbide precipitation which reduces the tensile strength in addition to the migration of carbon from mild steel to its counterpart super duplex stainless steel SAF 2507 will take place which is lead to formation of martensite layer [11,12] .Figures (10 11,12and 13) showed these micro transformation at the welded joints welded with

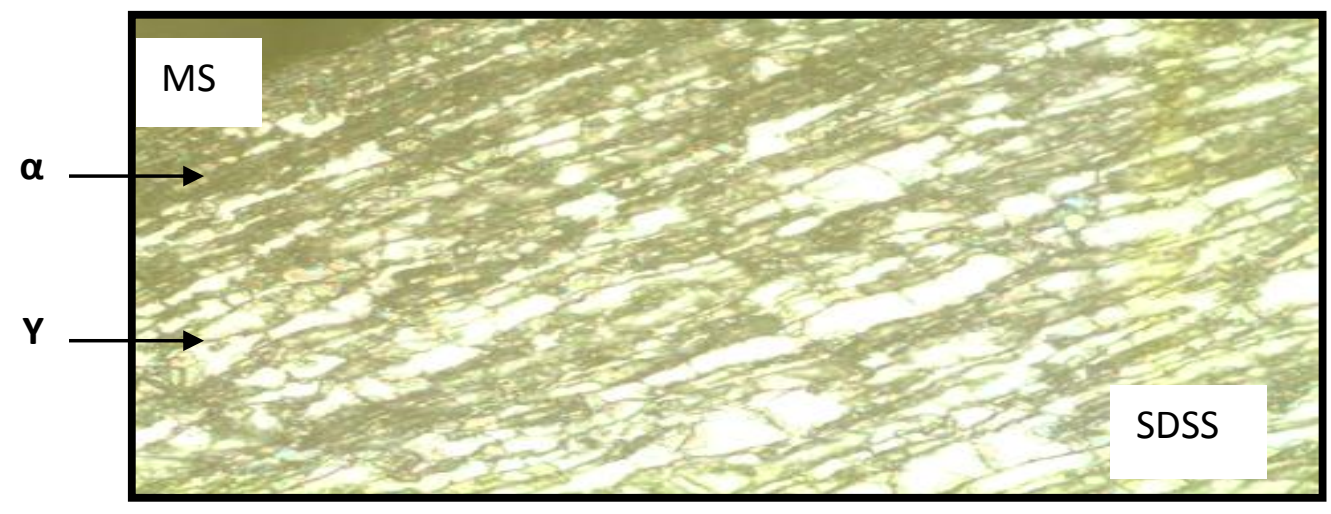

Fig. (10) Microstructure of dissimilar friction welded SDSS and MS joint interface (duplex side) case II (X600) 
intermediate and high friction welded parameters case II and III . Figure (13) shows the specimens after tension test.

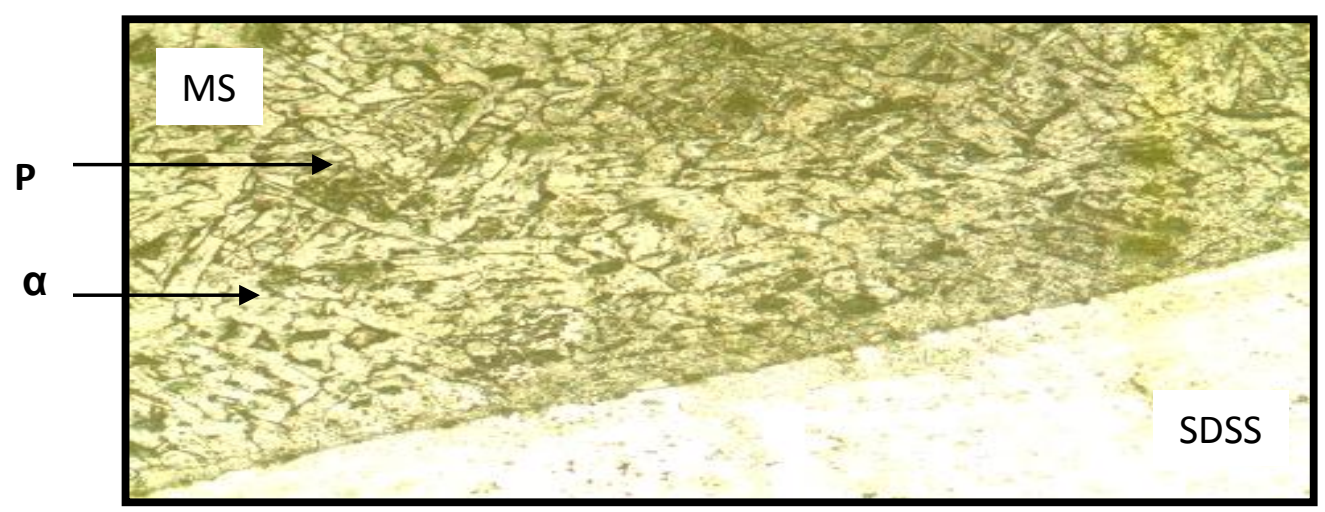

Fig (11) Microstructure of dissimilar friction welded SDSS and MS joint interface (MS side) case II (X600)

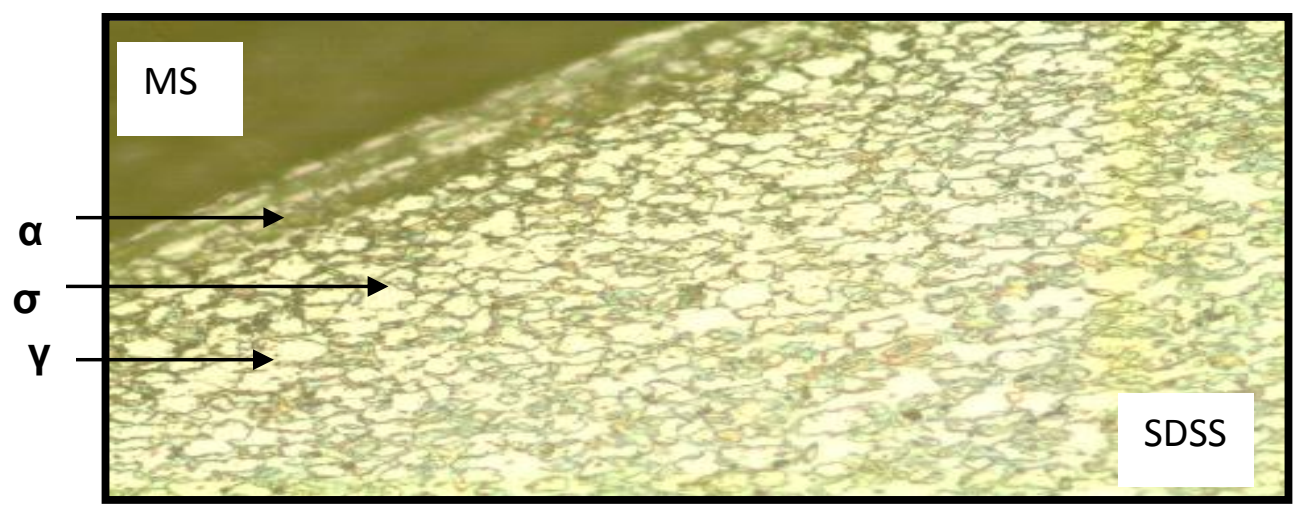

Fig. (12) Microstructure o of dissimilar friction welded SDSS and MS joint interface (duplex side) case III (X600), $\sigma=$ sigma

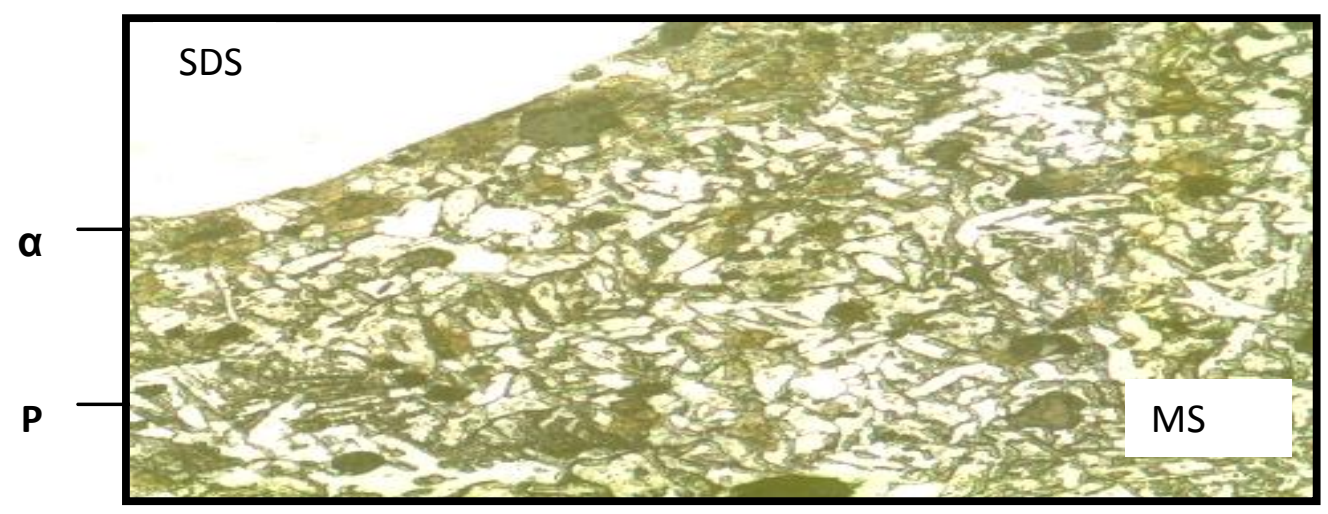

Fig. (13) Microstructure of dissimilar friction welded SDSS and MS joint interface (MS side) case III (X600) 


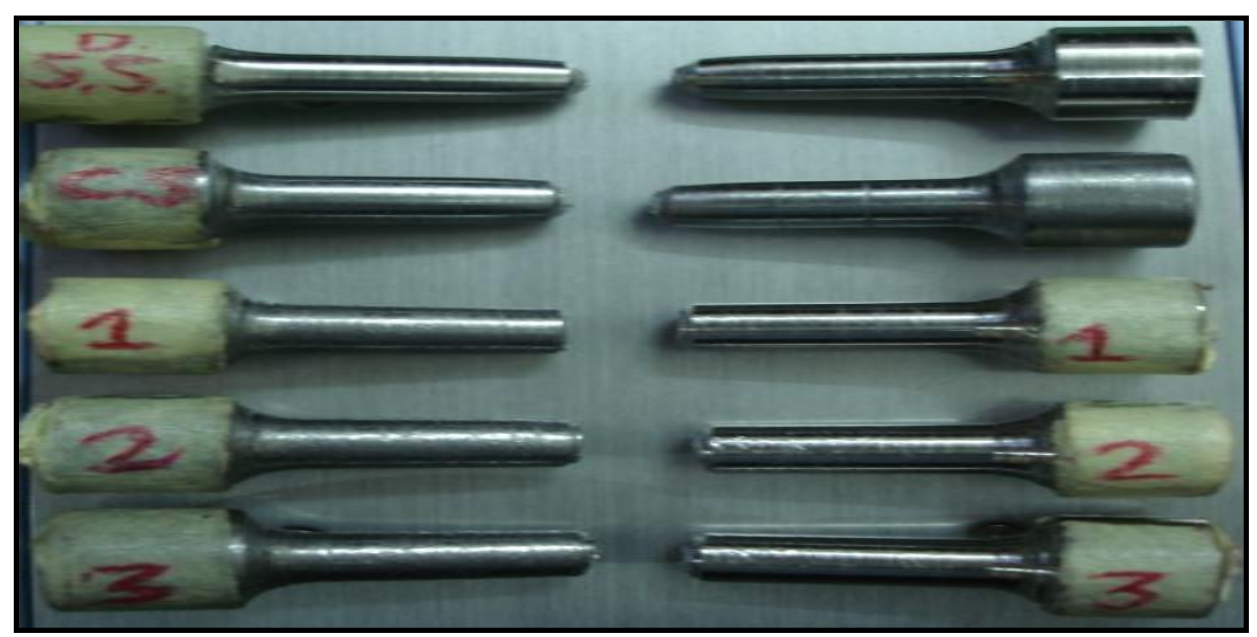

Fig. (14)Specimens after completion of tensile Tests

\section{Conclusions}

1. Friction welding can be used successfully to join super duplex stainless steel SAF 2507 and mild steel.

2. Dissimilar friction welding (SDSS SAF 2507-Mild steel) joints exhibit (66.12- 79.17\%) of weaker metal (mild steel) tensile strength.

3. Efficiency of dissimilar friction welded (SDSS SAF 2507-Mild steel) joints decreased with increasing friction pressure and forging pressure.

\section{References}

[1]. Echnrod J.J. and Opinnow K.E. "Effect of chemical composition and thermal history on the properties of alloy 2205 DSS " Proc Conf. "New development in stainless steel technique ,Detriot,Paper No. 8410-029 pp. 77 (1985).

[2]. Duplex stainless steel, Sandvic SAF2507 material data sheet S1875ENG May (2008).

[3].Moritoshi M., and Okita K.,Friction welding of dissimilar metals. Journal of the Japan welding society, Vol.71, No.6, PP.20-24, (2002).

[4]. Sahin M., and Akata H. , An Experimental study on friction welding of medium carbon and austenitic stainless steel components " Int.Lubr.Tubol,Vol.56(2)129,(2004).

[5]. Satyanarayanan V., Reddy G. and Mohandas T., Effect of surface roughness on the friction welded Austenitic -ferritic stainless steel dissimilar joint, IE I journal -MM, Vol. 188, April( 2007).

[6].Kurt A., Uygure I , and Palyasan U ." Effect of friction welding parameters on mechanical and microstructure properties of dissimilar AISI 1010-ASTM B22 joint", Welding journal ,Vol.90,PP.102-106. May (2011).

[7].Hascalik A. , Unal E. ,Ozdamir N. "Fatigue behavior of AISI 304 steel to AISI 434 steel weld by friction welding "Journal of Material Sci., Vol. 41,Pp. 3233-3239.(2006).

[8].Eder P. A. ,Francisco P. N. , and Chen Y. A., " Welding of AA1050 aluminum with AISI 304 Stainless steel by rotary friction welding process " Journal of Aerosp. Technol, Vol.2, Npp.301-306, Sep-Dec.(2010).

[9]. ASTM standard test method for metallographic of metals, in annual book of ASTM standard, Vol. 03-0.02, Philadelphia PA: ASTM (1978)

[10].Seong Y.K.,Seung B.J.,and Chang C.S."Mechanical properties of copper to titanium joint by friction welding "Journal of material science PP.1281-1287.(2003). 
[11].Barnhouse E.J. and Lioppoid J.C., Microstructure/Property relationship in dissimilar weld between duplex stainless steel and carbon steels. Weld journal, Vol.77, No12, PP.477-787(1998).

[12].Kotecki D.J., A martensite boundary on the WRC -1992 diagram, Weld journal, Vol.78, No5, PP180-192,(1999). 